\title{
Lumen-apposing metal stent for pediatric use: report of a challenging case
}

Endoscopic ultrasound (EUS)-guided interventions are as feasible in pediatric populations as they are in adult patients [1]. However, some special features must be considered: the ducts are smaller and thinner, and require special care by the endoscopists [1-3]. Adult endoscopes and devices can be used safely in children $>3$ years of age or $>15 \mathrm{~kg}$ in weight, according to the literature $[1,4]$. However, lumen-apposing metal stents (LAMS) have rarely been used in pediatric patients without adverse events [5].

A 2-year-old boy, $10 \mathrm{~kg}$ in weight, presented with choledocholithiasis and severe gastroesophageal reflux disease. He was also affected by multicystic encephalopathy. He underwent laparoscopic cholecystectomy, Nissen fundoplication, and surgical gastrostomy during the same operation.

On the eighth postoperative day, a bile fistula appeared from the surgical drain, and an abdominal ultrasound scan was performed, which showed a large fluid collection in the right hypochondrium. Surgical revision was decided, and a suspect accessory cystic duct was clipped during surgery.

On the 14th postoperative day, blood tests showed an increase in cholestatic enzymes, and a second abdominal ultrasound scan showed dilation of the intrahepatic biliary tree. The patient was referred to our unit because of onset of jaundice.

We decided to perform an endoscopic retrograde cholangiopancreatography, which showed complete post-surgical disconnection and closure of common bile duct at the level of the main hepatic confluence (Type III stricture according to Bismuth classification). The parents of the patient refused any surgery (a hepaticojejunal anastomosis was proposed) and, between percutaneous transhepatic biliary drainage and EUS-guided hepaticoduodenostomy, they chose the latter and signed the informed consent for the procedure.

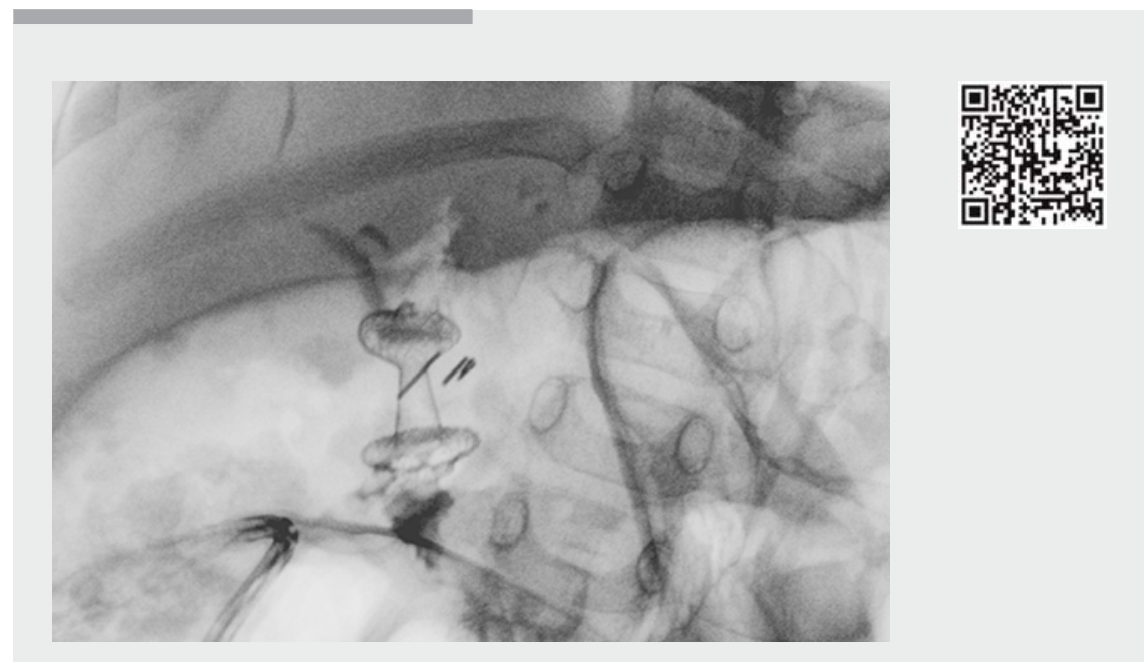

$\checkmark$ Video 1 Endoscopic hepaticoduodenostomy in a 2-year-old patient for complete postsurgical stenosis of the common bile duct. The procedure was complicated by misplacement of the stent during opening. We treated the complication endoscopically, and finally placed a second lumen-apposing metal stent.

Using a linear echoendoscope (EG-3870 UTK; Pentax, Tokyo, Japan), which was introduced directly through the site of the gastrostomy (enlarged during the endoscopic procedure), we confirmed the dilation of the biliary tree at the confluence of the hepatic ducts. We performed the hepaticoduodenostomy using the Hot Axios Stent and Electrocautery Enhanced Delivery System (Boston Scientific, Marlborough, Massachusetts, USA). The stent was $8 \mathrm{~mm}$ in diameter and $8 \mathrm{~mm}$ in length. However, the distal edge of the stent, which had been placed correctly at the beginning of the procedure, was misplaced proximally during opening into the peritoneal cavity.

The stent was removed and, using a duodenoscope (EC38-i10M; Pentax), we were able to cannulate the left hepatic duct under fluoroscopy with a curved hydrophilic guidewire (NaviPro; Boston Scientific) passing through the perforation in the duodenal wall that was created by the LAMS - and place a second LAMS $(8 \mathrm{~mm}$ diameter, $8 \mathrm{~mm}$ length; Boston Scientific). At cholangiography, the stent obstructed the right hepatic duct, so we adapted the distal bumper of the stent using an $8 \mathrm{~mm}$ Fogarty balloon (Cook Medical, Bloomington, Indiana, USA) until we obtained correct opacification of the whole biliary tree ( $\triangleright$ Video 1 ).

The post-procedural course was uneventful, and the blood tests returned to normal in 5 days. The patient was doing well at 6-month follow-up.

Endoscopy_UCTN_Code_CPL_1AL_2AC

Competing interests

None

The authors

Massimiliano Mutignani ${ }^{1}$, Edoardo Forti ${ }^{1}$, Alberto Tringali ${ }^{1}$, Marcello Cintolo ${ }^{1}$, Diego Falchetti² ${ }^{2}$ Vincenzo Argento $^{2}$, Lorenzo Dioscoridi ${ }^{1}$

1 Diagnostic and Interventional Digestive Endoscopy, Niguarda Ca-Granda Hospital, Milan, Italy

2 Pediatric Surgery, Niguarda Ca-Granda Hospital, Milan, Italy 


\section{Corresponding author}

\section{Massimiliano Mutignani, MD}

Endoscopy Unit, Niguarda Ca-Granda

Hospital, Piazza dell'Ospedale Maggiore 3,

20162, Milano, Italy

Fax: +39-02-64442911

massimiliano.mutignani@ospedaleniguarda.

\section{References}

[1] Prachayakul V, Aswakul P. Endoscopic ultrasound-guided interventions in special situations. World J Gastrointest Endosc 2016; 8: 104-112

[2] Varadarajulu S, Wilcox CM, Eloubeidi MA. Impact of EUS in the evaluation of pancreatobiliary disorders in children. Gastrointest Endosc 2005; 62: 239-244
[3] Attila T, Adler DG, Hilden K et al. EUS in pediatric patients. Gastrointest Endosc 2009; 70: $892-898$

[4] Scheers I, Ergun M, Aouttah T et al. Diagnostic and therapeutic roles of endoscopic ultrasound in pediatric pancreaticobiliary disorders. J Pediatr Gastroenterol Nutr 2015 61: $238-247$

[5] Nieto ], Hathaway K. Endoscopic ultrasoundguided pseudocyst drainage using a novel lumen-apposing metal stent (AXIOS) in two pediatric patients. Am J Gastroenterol 2014; 109: S597

\section{Bibliography}

DOI https://doi.org/10.1055/s-0043-123820

Published online: 15.12.2017

Endoscopy 2018; 50: E57-E58

(c) Georg Thieme Verlag KG

Stuttgart · New York

ISSN 0013-726X

\section{ENDOSCOPY E-VIDEOS}

https://eref.thieme.de/e-videos

回回 Endoscopy E-Videos is a free access online section, reporting 田: on interesting cases and new techniques in gastroenterological endoscopy. All papers include a high quality video and all contributions are freely accessible online.

This section has its own submission website at

https://mc.manuscriptcentral.com/e-videos 